\title{
АНТИРАДЯНСЬКА ПРОПАГАНДА ЯК ОСНОВНА КОМУНІКАТИВНА СТРАТЕГЕМА В ДРУКОВАНИХ ПЕРІОДИЧНИХ ВИДАННЯХ 1943 РОКУ (НА МАТЕРІАЛІ АНАЛІЗУ ГАЗЕТИ «ВІДРОДЖЕННЯ»)
}

\author{
Оксана Почапська \\ Кам'янець-Подільський наџіональний університет імені Івана Огієнка \\ вул. Огієнка, 61, 32300, м. Кам'янець-Подільський, Хмельницька обл., Украӥна \\ e-mail: oksanapochapska25@gmail.com \\ https://orcid.org/0000-0003-1069-9639
}

У статті розглянуто основні аспекти формування системи комунікації редакцією газети «Відродження». Оскільки газета мала відкриту антирадянську позицію, стратегічний вибір комунікативного вектору в переломних умовах формувався із урахуванням найбільш вразливих позицій для розвитку української нації. Мова йшла про об'єднання українського населення навколо економічного, культурного, політичного й силового мотиваторів.

Автор доходить висновку, що основним стратегічним напрямом формування інформаційних повідомлень у газеті «Відродження» була концепція вищості німецької нації, яка готова прийти на допомогу українцям у формуванні якісно нової, вільної від радянського правління держави.

Ключові слова: стратегема, стратегічні комунікації, преса, газета «Відродження».

Постановка проблеми. Характеризуючи інформаційне поле України 19431991 рр., дослідники журналістики досі акцентували увагу здебільшого на партійно-радянській пресі. Безперечно, в кількісному масштабі ця преса була наймасовішою. Водночас до періоду встановлення державності України партійно-радянську пресу характеризували лише позитивно. Після 1991 р. почали з'являтися окремі публікації, в яких ЗМІ окресленого періоду, передовсім під впливом як українських, так і закордонних істориків, почали вивчати об'єктивно, з'ясовувалася їх деструктивна роль в житті української нації. Зокрема, вагома роль у цьому належить історикам Я. Грицаку, Я. Дашкевичу, К. Кондратюку, О. Сухому, Ю. Шаповалу, І. Патеру та ін.

Однак цілісних наукових досліджень, присвячених вивченню української преси 1943-1991 pр. в історико-журналістській науці, досі немає, якщо не рахувати окремих статей, надрукованих в наукових журналах (М. Житарюк, Ю. Колісник, О. Мукомела, І. Павлюк, Н. Сидоренко, Ю. Колісник та ін.).

Незважаючи на потребу заповнення «білих» і «чорних» плям в українському журналістикознавстві, існує водночас потреба в переосмисленні діяльності партій-

(C) Почапська O., 2019 
но-радянської преси, вивченні творчості публіцистів, які намагалися різними шляхами донести до читачів правду про пропагандистську роль радянської преси, показати її негативне значення для української нації.

Досі поза увагою дослідників залишаються періодичні видання антирадянського спрямування (в тому числі й пронімецька періодика), які виходили друком на окупованих німецькими військами територіях.

Аналіз останніх досліджень 3 проблематики роботи. Загалом явище пропаганди і їі впливу на свідомість українського населення через засоби масової інформації вивчалися і продовжують вивчатися такими науковцями, як В. Лизанчук [5; 6], I. Крупський [3; 4], Г. Почепцов [11], О. Холод [12] та ін. Вказані дослідники розглядають пропаганду як явище в сучасному суспільстві, або в історичному контексті, а також - ¥ї вплив на формування свідомості сучасного населення України.

У друкованих періодичних виданнях, які так чи інакше протистояли радянській пропагандистській машині, стратегію донесення інформаційних повідомлень досліджували В. Пастушина [7], М. Чабаненко [13] та ін. Подібні публікації розглядають або сучасні українські 3МI, або виключно проукраїнські ЗМІ, які виникали на території України в XX столітті. I практично не звертається увага на ЗМІ окупаційної німецької влади.

Разом $з$ тим, позитивізуючи (як це було у радянському журналістикознавстві) чи абсолютно відкидаючи методологію формування інформаційного простору періодичними виданнями 1943-1991 років, дослідники залишають сучасне суспільство iз завданням винаходити те, що було винайдене. Загальносвітовий політичний контекст, в якому сьогодні формується власне український інформаційний простір, необхідність відпрацювання і вдосконалення методології інформаційного захисту та становлення свідомісного розуміння сучасними журналістами необхідності вироблення стратегії й тактики формування міцних інформаційних полів (як зовнішніх, так і внутрішніх) актуалізують обрану тему дослідження.

Мета дослідження - розгляд особливостей антирадянської пропаганди як основи комунікативної стратегеми в друкованих періодичних виданнях 1943 року (на матеріалі аналізу газети «Відродження»).

Вивчаючи стратегічні напрями антирадянської пропаганди, ми будемо відштовхуватися від такого визначення: «Пропаганда (від лат. propaganda - те, що підлягає розповсюдженню, propagare - плекати саджанці) - популяризація, поширення, роз'яснення і навіювання політичних, філософських, наукових, релігійних, художніх та інших ідей, вчень, знань, поглядів, оцінок засобами масової інформації, усно, писемно, аудіовізуальними та іншими методами впливу на індивідуальну і суспільну свідомість» [6, с. 112].

Досліджуючи особливості сучасної російської пропаганди, В. Лизанчук зазначає, що «у країнах з тоталітарним режимом пропаганда стала державним завданням. Наприклад, у нацистській Німеччині та комуністичному Радянському Союзі була створена спеціальна сітка партійно-урядових закладів, у яких працювали навчені пропагандистські кадри. Сітка пропаганди охоплювала всі сфери суспільства, підприємства, установи, навчальні заклади, армію тощо. Особливу ідеологічно-пропагандистську роль відігравали засоби масової інформації» [5, с. 22]. Причому і Німеччина, і Радянський союз так чи інакше намагалися поширювати пропагандистські ідеї не лише на власних територіях, але і на територіях ворожих. 
1943 рік для України став переламним роком, коли радянські війська почали відвойовувати українські території у німецьких військ. Окупаційні режими, ділячи між собою території, опинилися на стадії не лише збройних протистоянь, але й повноцінної інформаційної війни: пропаганда в періодичних виданнях, як з одного, так і з іншого боку, була покликана сформувати у свідомості аудиторії чіткі уявлення про країну, яка спонсорує пропаганду.

На території України у 1943 році досить сильною була антирадянська пропаганда. Провідним пронімецьким виданням була газета «Відродження», яка виходила друком у 1941-1943 роках у Ромнах двічі на тиждень як орган Роменської міської управи. Газета мала наклад 10-17 тис. примірників, що було досить вагомим як на видання цього періоду.

Газета регулярно вміщувала відозви і звернення Адольфа Гітлера, де мова йшла про здобутки німецької армії, про втрати радянських військ, а також про основні стратегічні напрямки розвитку України під проводом Німецької Республіки. При цьому, найважливіші репліки були виділені напівжирним шрифтом. До прикладу: «У своій відозві до німецького народу, випущеній у 10-ту річницю переобрання влади національно-соціялістичною партією, Адольф Гітлер знаменними словами оцінив большевицьку небезпеку, яку раз на завжди треба відвернути від Европи: «Коли б ияя небезпека звалилась на Европу, - сказав Фюрер, - Европа загинула б, як ие вже сталося з російським народом». Ці лосва характеризують підхід націонал-соиіялістичної Німеччини до проблеми большевизму та східних народів. Націонал-соціялізм, який репрезентує нову Европу, ні в якому разі не вважає народи Сходу за втілення большевизму, навпаки - вважає їх за об'єкт большевицького нападу, за мучеників, за жертву. Отже, боротьба Німеччини та Европи (знову підкреслює Фюрер) зовсім не спрямована проти Сходу, як такого, чи проти населення цьього простору, - ие боротьба проти режиму, що 25 років тримав цуе населення в неволі, а тепер з такою самою кровожадністю зазіхає на всю Европу» [2, с. 1].

Подібні виділення мали на меті не лише привернення уваги читача, але й формування правильної акцентної групи, яка повинна була стати базовою для сприйняття інформаційного повідомлення. По суті, мова йде про співчуття, яке в умовах тотального нерозуміння позицій «друг» і «ворог» стає тією емоційною складовою, яка здатна не лише сформувати систему сумнівів у свідомості українського населення, але й сформувати чітке переконання того, в якому напрямку найпродуктивніше рухатися для формування перспективних напрямів суспільного розвитку.

Для підсилення негативізації образу радянської влади і радянської армії було введено серію репортажних публікацій про те, як живуть українці під керівництвом радянської влади, де обов'язково підсилювалася інформація про нестачу продовольчих товарів, про формування космополітичної концепції співіснування ментально різнорідних народів під егідою Радянського Союзу. Останнє особливо стосувалося негативного ставлення до культурних надбань українського народу, в контексті опису якого максимально підкреслювалося бажання німецької влади сформувати власне український культурний осередок через відзначення дня народження і дня смерті Тараса Шевченка, а також через формування музеїв українських старожитностей: «Один із них - нейтральний дипломат, який відпочиває тепер у своїй рідній країні, дуже докладно змалював співробітникові франиузького часопису «Ваянс» картину теперішньої ситуації життя в Москві. Життя в кремлівській столиці, - розказує 
він, - майже зовсім завмерло. Тільки в народних комісаріятах та інших совєтських установах іде ще деяка регулярна робота. Там працюють переважно жінки. Праиюють вони біля неймовірно брудних столів, у кімнатах, де вже місяцями як слід не вбиралося, сидять у пальтах, загорнувшись у шалі, бо в Москві взагалі не опалюють помешкань. Школи у Москві зачинені. Тільки одна єдина школа-десятирічка не припинила своєї роботи. Там «відповідно до моменту» стариих учнів навчають методу шпигунства та саботажу...» [14, с. 2].

Контрастність подібних публікацій формує ілюзію інформаційного вибору: між тотальним контролем в умовах СРСР і можливістю національно-культурного розвитку під егідою Німецької Республіки. Емоційність подібних дописів підсилювалася за допомогою коротких речень, які викладали факти, котрі населення не мало змоги достеменно перевірити, що ставило їх у ситуацію вибору: довіряти ЗМІ чи довіряти уривкам чуток, які періодично доносилися з тих територій, які були підпорядковані СРСР.

Авторитет, який здобули ЗМІ ще в XIX столітті, коли вони були чи не єдиним джерелом інформування населення, унеможливлював сумніви, котрі могли би виникати стосовно толерантності Німецької Імперії до національно-культурного розвитку українства.

Активно в газеті анонсувалася підтримка німецькою владою розвитку аграрного господарства на території Роменської області: «Для Роменської області одержано з Німеччини новий препарат «Церезан» - отрута для боротьби з хворобою на зернових культурах - головнею.

«Церезан» громадські двори та держмаєтки одержують по розпорядках з Роменського с.-г. постачання» [10, с. 2].

Така інформація була покликана сформувати імідж прогресивного керівника (мова йде про Німецьку Імперію), який дбає про все населення та його розвиток і добробут. Подібна інформація створювала своєрідні гачки, на які чіплялося населення, що всіляко сприяло утвердженню німецької влади на території України.

В цьому ж контексті подається інформація про те, чому необхідно (і навіть дуже прогресивно) їхати на роботу до Німеччини: «Не тяжко передбачити, які переваги будуть мати ті, хто сьогодні першими поїдть до Німеччини.

Вони пери за все вивчать німецькі методи виробництва та оволодіють ними.

Вони швидко навчаться досконало говорити на німецькій мові.

Після укладання миру вони, звичайно, матимуть в украӥнському господарстві периі й краще за все оплачувані місця. $[15$, c. 3$]$.

Вони будуть переважати своӥх братів й сестер, які не бачили Німеччини...»

30 номер газети присвячена Адольфу Гітлеру. На титульній сторінці - портрет Адольфа Гітлера (див. Рис. 1). Далі на кількох розворотах подається біографія лідера, а тоді - інформація про його найбільші досягнення в галузі культури, освіти, стримування розповсюдження більшовицького режиму в країнах Західної Свропи.

Інформація про перемоги на лінії фронту, кількість збитих радянських літаків і танків щономера подавалися на першій шпальті («За час з 16-го по 19-те квітня збито 178 совєтських літаків» [1, с. 1], «Під Новоросійськом збито 91 совєтський літак» [9, с. 1] та ін.): «Верховне Командування Німецььких Збройних Сил повідомляє: 


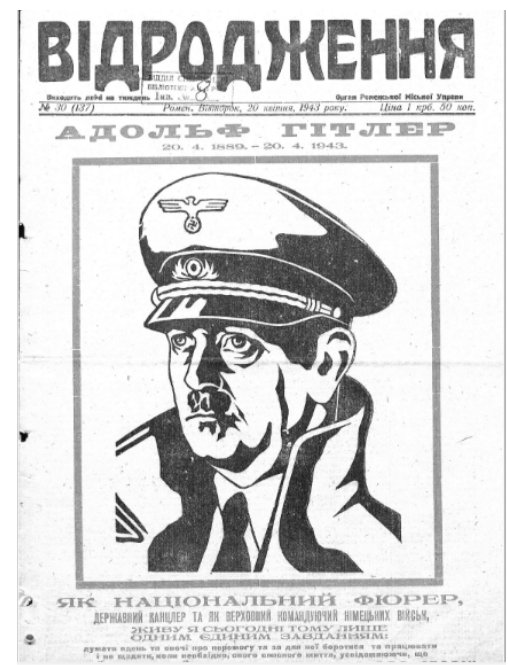

Рис. 1. Титульний листок газети «Відродження»

На південь від Новоросійська тривають запеклі бої, у яких знову з міиними силами втручилася авіація.

На західному узбережжі Кавказа бойові літаки затопили один ворожсий швидкісний човен та пошкодили три судна ... [...]

За час з 16-го по 19-е квітня були знищені 178 совєтських літаків. 11 власних літаків загинули на той же час...» [1, с. 1].

Аналізуючи певну приналежність населення до радянського соціуму, сприйняття ним свят (які були нав'язані більшовиками), німецькі стратеги і тактики не намагалися відірвати українців від нав’язаних порядків, але модифікували їх під себе, надаючи їм нового змісту і кардинально нового звучання: «B той час, коли мільйони людей ще недооиінюють значення фізичної праці, ми хочемо виховати нарід в свідомості, щзо фізична праия не ганьбить, аяк і кожна інша діяльність служить пошаною тому, хто їі вірно та чесно виконуе (Адольф Гітлер).

Шануйте працюю та поважайте робітника!» [8, с. 1-2].

Трапляються критичні публікації в бік опозиційних країн: тут подається аналіз ситуації (і в першу чергу, економічної), яка склалася через «недолугі» (за визначенням журналістів-пропагандистів) дії влади, яка працювала виключно на задоволення власних потреб, забуваючи про потреби населення власної країни.

Висновки і перспективи подальших досліджень. Таким чином, пропагуючи діяльність німецьких військ і політику Німеччини в цілому, газета акцентує увагу на тих негативних наслідках, які приніс із собою більшовизм, а також усіляко підкреслює, що націонал-соціалісти прагнуть забезепечити народи Сходу таким самим рівнем життя, як в Європі. Окрім того, підкреслюється намагання Німеччини піклуватися про українців через розвиток культури і сільського господарства. На сторінках газети подаються детальні звіти про проведення днів вшанування пам'яті українських письменників (до прикладу, Тараса Шевченка, Івана Франка та ін.), передрук творів і уривків творів як німецьких, так і українських письменників. Окрім 
того, інформується населення і про те, які кроки робить Німеччина для розвитку аграрної промисловості на території України («Препарат “Церезан”»).

Для підкреслення позитивних зрушень, які приносять із собою соціал-демократи, в газеті використовуються в якості протиставлення інформаційні й інформаційно-публіцистичні повідомлення про негативні наслідки життя в умовах більшовизму («Як живе сьогодні совєтська людина»). При цьому використовується прийом оповіді від імені реальної людини, яка на власні очі бачила те, що тепер переказує.

Перспективою подальших досліджень $є$ вивчення особливостей поширення антирадянської пропаганди на теренах України під час Другої Світової війни, коли інформаційні процеси концентрувалися переважно навколо таких інформаційних точок, як військові перемоги і втрати, а також відбудова СРСР після перемоги над німецькими військами.

\section{REFERENCES}

1. За час з 16-го по 19-е квітня збито 178 совєтських літаків // Відродження. 1943. №31 (138). C. 1 .

2. 3 Німеччиною проти большевизму : боротьба народів Сходу // Відродження. №25 (132). 2 квітня. С. 1.

3. Крупський I. Пропагандистсько-маніпуляційна діяльність російського телебачення як чинник розпалювання міждержавної ворожнечі / І. Крупський // Теле- та радіожурналістика. 2015. Випуск 14. С. 179-187.

4. Крупський I.В. Цензура й українські ЗМІ: історія й сучасність / І. В. Крупський // Держава та регіони. Серія: Соціальні комунікації. 2013. № 2 (14). С. 83-87.

5. Лизанчук В. Просвітницька і маніпулятивна пропаганда в умовах нинішньої російсько-української війни / В. Лизанчук // Теле- та радіожурналістика. 2018. Випуск 17. С. 22-51.

6. Лизанчук В. Психологія мас-медіа: підручник / В. Лизанчук. Львів : ЛНУ імені Івана Франка, 2015. 420 c.

7. Пастушина В. Пропаганда як ідеологічна складова журналів «Сурма» та «Розбудова нації» // Вісник Львівського університету. Серія Журналістика. 2018, № 44. C. 22-27.

8. Перше травня - день визволення від большевизму праці // Відродження. № 32 (139). 1 травня. С. $1-2$.

9. Під Новоросійськом збито 91 совєтський літак // Відродження. 1943. № 31 (138). C. 1.

10. Препарат «Церезан» // Відродження. 1943. № 26 (133). 6 квітня. С. 2.

11. Почепцов Г. Пропаганда уверенно шагает в будущее / Г. Почепцов. Електронний pecypc. - Режим доступу: https://psyfactor.org/lib/propaganda58.htm (дата звернення: 08.02.2019).

12. Холод О. Інмутація суспільства в гіпермаркеті свідомості : у 3 т. Т. 1 : Теорія інмутації суспільства : монографія / Олександр Холод. К. : КиМУ, 2010. 213 с.

13. Чабаненко М. Журналістика і пропаганда: у пошуках правильних рішень [Електронний ресурс] / М. Чабаненко // Медіакритика. - Режим доступу: http:// www.mediakrytyka.info/za-scho-krytykuyutmedia/zhurnalistyka-i-propahanda -u-poshukakh-pravylnykh-rishen.html 
14. Як живе сьогодні совєтська людина // Відродження. 1943. № 26 (133). 6 квітня. С. 2. 15. Які переваги мають від’іжджаючі на роботу до Німеччини // Відродження. 1943. № 32 (139). 1 травня. С. 3.

\title{
ANTISOVIET PROPAGANDA AS THE BASIC COMMUNICATIVE STRATEGY IN PRINTED PERIODICAL EDITIONS OF $1943^{\text {th }}$ (THE ANALISYS OF THE NEWSPAPER «VIDRODZHENNIA»)
}

\author{
Oksana Pochapska \\ Kaminaets-Podilskyj Ivan Ohiienko National University \\ 61 Ohienko str., Kamianets-Podilsky, 32300, Khmelnytsky reg, Ukraine \\ e-mail: oksanapochapska25@gmail.com \\ https://orcid.org/0000-0003-1069-9639
}

The article deals with the main aspects of the formation of the system of communication by the editorial staff of the newspaper «Revival» («Vidrodzhennia»). As the newspaper had an explicit anti-Soviet standpoint, the strategic choice of a communicative vector in abrupt circumstances (since 1943rd Soviet troops gradually began to win Ukrainian lands from German troops) were formed taking into account the most vulnerable positions that were fundamental to the development and formation of the Ukrainian nation. It was about uniting the Ukrainian population around the economic (decent wages, comfortable conditions, a chance to improve their qualifications and return to Ukraine in order to develop a specific industry in Ukrainian economic conditions), cultural (celebrating those religious holidays that are inherent in the culture of the Ukrainian population), political (strategically correct Adolf Hitler, which will lead to the formation of a qualitative new state education that will be able to overcome the USSR) and force (the victory of the German troops on various fronts) motivators.

Such an approach to informing the population was the reason that some Ukrainians actively supported the policy of the German authorities in the occupied territories. And this, in turn, led to a national split and formed a system of denunciations and espionage. Similar methods were used in Soviet propaganda.

The author comes to the conclusion that the main strategic direction in the formation of informative messages in the newspaper «Revival» («Vidrodzhennia») was the concept of the choice of the German nation, which is ready to help Ukrainians in the formation of a qualitatively new, free from the Soviet government country.

Key words: strategy, strategic communications, press, newspaper «Revival» («Vidrodzhennia»). 